\title{
Socioeconomic Analysis of Alternative Farming Systems in Improving Livelihood Security of Small Farmers in Selected Areas of Bangladesh
}

\author{
Sadika Sharmin ${ }^{1}$, M. Serajul Islam ${ }^{2 *}$ and Md. Kamrul Hasan ${ }^{3}$ \\ ${ }^{1}$ School of Health Science, Universiti Sains Malaysia, Pulau Pinag, Malaysia \\ ${ }^{2}$ Dept. of Agricultural Economics, Bangladesh Agricultural University, Bangladesh \\ ${ }^{3}$ Spices Research Centre, Bangladesh Agricultural Research Institute, Bogra, Bangladesh \\ *Corresponding author and Email: serajulbau@yahoo.com
}

Received: 30 December $2011 \quad$ Accepted: 26 May 2012

\begin{abstract}
The present study attempted to determine the economic returns of alternative farming system of integrated farming aiming to address the livelihood security of small farm households. One hundred and sixty small and medium farmers practicing in four different FS such as Crop-Poultry (C-P), CropPoultry-Pond fisheries (C-P-F), Crop-Livestock-Poultry (C-L-P) and Crop-Livestock-Poultry-Pond fisheries (C-L-P-F) were selected from Mymensingh, Jamalpur and Sherpur district. The main information collected were socio-demographic characteristics of farm households, household income from farm and non-farm sources, size of land holding and farming system followed, livestock and poultry rearing and pond fish culture, and effect of integrated farming on household income and livelihood security of small farm households. Data were collected covering one production period during 2009-2010. For estimating farm income of small farm household, whole farm approach was considered. Increased number of farm enterprises caused higher farm income. However, considering the small farm practices and whole farm approach, the farm income as well as net return was higher for C-L-P-F farmers (Tk. 57002), followed by C-L-P (Tk. 52978), C-P-F (Tk. 20447) and C-P (Tk. 13734) farmers. Some of the most commonly used factors in the assessment of livelihood security included those related to household income and expenditure, expenditure spent on food, adequacy of food taken, household structure and facilities, owning household assets, and access to drinking water and sanitation, and other basic needs of farm household. All these socioeconomic factors were found to be related livelihood security of small farmers in Bangladesh. Women were more involved in income earning activities and household decision making with the introduction of integrated farming in small farm condition.
\end{abstract}

\section{Keywords: Alternative farming system, livelihood security, integrated farming, small farmers}

\section{Introduction}

Bangladesh is one of the most densely populated countries in the world and as a result, per capita arable land is very low. Of the 17 million households in Bangladesh, about $80 \%$ are small farmers and some of these farmers are landless (BBS, 2009). Due to its subsistence nature, agriculture in Bangladesh is characterized by diversified farming to meet the household requirements and to minimize the risk and uncertainty. Small farmers try to develop as many enterprises as their farming systems (FS) allow within the present socioeconomic and agro-climatic condition, and in accordance with household goals, preference and resources. 
In this regard, land topography, soil composition, and availability of different inputs along with the environmental factors which influence the farmers in choosing different enterprises in their farming are considered. Accordingly, the interdependence of resources is usually higher in small farming compared to conventional farming and it also enhances soil fertility which in turn leads to total production and household income (Taj Uddin and Takeya, 2007).

Among all the farm households in Bangladesh of which about $25-30 \%$ are either landless or have land less than 0.05 acre (BBS, 2009). Secondly, a great majority (80\%) of landed farm households are small farmers owning land between 0.05 to 2.49 acres. Only 16 and $4 \%$ are medium and large farmers respectively. Farming activities in Bangladesh are generally concentrated for the production of crops, livestock, fisheries and agro-forestry. Except crops other activities are done mainly around the homestead area. Moreover, homestead farming is considered as alternative to produce necessary vegetables, fish, poultry and livestock (Islam et al., 1999; Hossain, 1996).

However, within the given components, farmers produce different types of enterprises such as cereals, oilseeds and vegetables within the crop component; cattle, goats, sheep and poultry in the livestock component; and culture and capture fisheries in fisheries component (Islam and Bakshi, 1992). Therefore, on the basis of enterprise combination, many types of farming systems are found in Bangladesh. Almost all the enterprises are interrelated and interdependent. Again, small farming is integrated in nature and from these enterprises farmers try to fulfill all the basic household needs for their families. In integrated farming, crops, cattle, fish and poultry enterprise might have higher profit for farms of all sizes. In particular, medium farmers performed the best in terms of benefit-cost ratio (BCR) and the absolute of net return per Taka invested (Taj Uddin and Takeya, 2005).

An understanding of how integrated farming contributes to increase household income of the small farmers by improving their livelihood security might encourage policy makers to improve the socioeconomic condition of small farmers through implementing integrated farming. Again, farmers would have idea about how integrated farming contributes to improve livelihood security of the household members under respective farming system. This study was therefore, undertaken to examine the integrated farming practiced under different farming system and its contribution to household income of small farmers and to determine the present socioeconomic condition of small farmers aiming to address their livelihood security being improved through integrated farming.

\section{Methodology}

\subsection{Study area and sampling}

The present study targeted mainly small farmers from three sadar upazilas of three districts namely Mymensingh, Jamalpur and Sherpur, respectively. For simplicity, sample households were categorized into two groups according to their size of holdings as small (0.05 - 2.49 acres) and medium farmers $(2.50-7.49$ acres $)$. Small and medium farmers who followed the respective farming system as shown in Table 1 were selected as sample farmers. Both small and medium farmers own small size of land and accordingly, land size (acre) was considered to determine the size of sample farmers.

Three villages were selected from each sadar upazila. A list of farmers was then prepared for each village in each upazila. From each upazila, respective number of farm households under different FS as shown in Table 1 was selected randomly from the list. In total 160 farmers were selected of whom 130 were small farmers and those of 30 were medium farmers.

\subsection{Data collection and analysis}

For this study, data and information were collected from the heads of the farm households. The information was collected through direct interview by the field investigators. Following the objectives of the study, a structured 
Table 1. Sampling design and distribution of farm households

\begin{tabular}{lcc}
\hline \multicolumn{1}{c}{ Farming System (FS) selected } & Sample farm households & Categories of farmers \\
\hline Crop-Poultry (C-P) & 50 & Small \\
Crop-Poultry-Pond fisheries (C-P-F) & 40 & Small \\
Crop-Livestock-Poultry (C-L-P) & 40 & Small \\
$\begin{array}{l}\text { Crop-Livestock-Poultry-Pond } \\
\text { fisheries (C-L-P-F) }\end{array}$ & 30 & Medium \\
\hline Total farm households & 160 & - \\
\hline
\end{tabular}

Note: In integrated farming, only major crops and enterprises were selected. In all the FS, only rice was included in crop component; poultry birds in scavenging condition in homestead areas; pond fishery in homestead area; and rearing cattle was included in livestock component

questionnaire was developed and used for the survey. The questionnaire was presented in the field and necessary changes were made before the final survey was conducted. Focus Group Discussions (FGD) were conducted to determine gender role and women participation in small farming and household activities. The main information collected were socio-demographic characteristics of farm households, household income from farm and non-farm sources, size of land holding and farming system followed, livestock and poultry rearing, and pond fish culture; and effect of integrated farming on household income and livelihood security of small farm households. Data were collected covering one production period during 20092010 .

Farm operators or owners of households were taken as the unit of analysis. The data and information so collected were coded, tabulated and analyzed by using arithmetic mean, percentage and ratio. Most of the analyses were done by categorizing the respondent households into two land ownerships groups - small and medium farmers under four different FS. However, sample households were drawn on the basis of land holding and number of cattle and poultry birds owned, and farmers practicing pond fish culture.

\section{Results and Discussion}

\subsection{Sociodemographic profile of farm households}

\subsubsection{Demographic profile of farm households}

The family and its composition are related to occupation and income. Table 2 shows that family size is related to the size of holdings. Medium farmers under the FS Crop-LivestockPoultry and Pond fisheries (C-L-P-F) had larger family size (5.75) than the small farmers (4.765.65) belonging to other alternate FS. Considering both categories of farmers, the average family size of all farmers was 5.25 persons, with $32 \%$ males and $26 \%$ of females in the 18 to 60 years age category and are considered as working members. However, the average family size of all farmers (5.25) appears to be higher than the national average of 5.48 members (BBS, 2009). Among the sample farmers, $29 \%$ had no education. Illiteracy rates were higher in case of small farmers compared to medium farmers. Considering all farmers, only 23 and $30 \%$ had primary and secondary level of education (Table 3). However, as the study areas were near to the sub-urban areas, literacy rate was considerably higher than the national average of $66 \%$ (BBS, 2009). 
Table 2. Family size and age distribution of household members of farm families

\begin{tabular}{|c|c|c|c|c|c|}
\hline \multirow{2}{*}{ FS Selected } & \multirow{2}{*}{$\begin{array}{l}\text { Family } \\
\text { members } \\
\text { (Nos.) }\end{array}$} & \multicolumn{2}{|c|}{ Family members } & \multicolumn{2}{|c|}{$\begin{array}{c}\text { 18-60 Years } \\
\text { (working members) }\end{array}$} \\
\hline & & Male (Nos.) & $\begin{array}{l}\text { Female } \\
\text { (Nos.) }\end{array}$ & $\begin{array}{l}\text { Male } \\
\text { (Nos.) }\end{array}$ & $\begin{array}{c}\text { Female } \\
\text { (Nos.) }\end{array}$ \\
\hline Crop-Poultry & 4.76 & 2.53 & 2.25 & 1.44 & 1.24 \\
\hline Crop-Poultry-Pond fisheries & 4.90 & 2.66 & 2.24 & 1.57 & 1.30 \\
\hline Crop-Livestock-Poultry & 5.65 & 3.15 & 2.52 & 1.75 & 1.48 \\
\hline $\begin{array}{l}\text { Crop-Livestock-Poultry- } \\
\text { Pond fisheries }\end{array}$ & 5.75 & 3.28 & 2.48 & 2.02 & 1.58 \\
\hline All farmers & $5.25(100)$ & $2.88(55)$ & $2.37(45)$ & $1.65(32)$ & $\begin{array}{l}1.38 \\
(26)\end{array}$ \\
\hline
\end{tabular}

Note: Figures within parenthesis indicate percentage of total number of members of households

Table 3. Average age and educational level of sample farmers

\begin{tabular}{lccccc}
\hline \multirow{2}{*}{ Farming system } & $\begin{array}{c}\text { Average age of } \\
\text { sample farmers }\end{array}$ & \multicolumn{4}{c}{ Level of education of farmers, \% } \\
\cline { 3 - 6 } & 45 & Illiterate & $1-5$ & $6-10$ & 11 and above \\
\hline Crop-Poultry & 40 & 66 & 17 & 17 & 0 \\
Crop-Poultry-Pond fisheries & 40 & 24 & 41 & 29 & 6 \\
$\begin{array}{l}\text { Crop-Livestock-Poultry } \\
\begin{array}{l}\text { Crop-Livestock-Poultry-Pond } \\
\text { fisheries }\end{array}\end{array}$ & 43 & 10 & 20 & 40 & 30 \\
\hline All farmers & 42 & 0 & 12 & 42 & 46 \\
\hline
\end{tabular}

Table 4. Distribution of principal occupation of sample farmers (\%)

\begin{tabular}{lccc}
\hline Farming System & Farming & Petty trading $^{*}$ & Others $^{\mathrm{I}}$ \\
\hline Crop-Poultry, $\mathrm{n}=50$ & 80 & 10 & 10 \\
Crop-Poultry-Pond fisheries, $\mathrm{n}=40$ & 85 & 10 & 5 \\
Crop-Livestock-Poultry, $\mathrm{n}=40$ & 88 & 10 & 2 \\
Crop-Livestock-Poultry-Pond fisheries, $\mathrm{n}=30$ & 90 & 5 & 5 \\
\hline All farmers, $\mathrm{n}=160$ & 86 & 8 & 6 \\
\hline
\end{tabular}

IOthers: services, wage labourers, risksacrew puller, earth workers etc. 


\subsubsection{Household occupational profile}

Irrespective of farmers belonged to different FS, the overwhelming majority (86\%) of sample farmers had farming as principal occupation (Table 4). Farming included crop production, livestock rearing and to some extent, pond fish farming and poultry rearing. Livestock rearing (stall feeding), poultry rearing (scavenging condition) and homestead pond fish production were considered as supplementary activities for small farmers. Only $8 \%$ of them were principally occupied with business and other $6 \%$ were engaged in salaried job and other works such as wage laborers, rickshaw pullers and earth workers.

\subsection{Land holding and alternate farming system}

\subsubsection{Land ownership and size of holding}

Table 5 presents the ownership pattern and tenurial arrangements for the different categories of farmers. Farmers practicing first three alternate FS as shown in Table 5 are the small farmers and the last one (C-L-P-F) are the medium farmers. Average farm size varied widely between small and medium farmers and even there was a small variation within the small farmers group in the study areas. Usually, small farmers are resource poor with small land holdings. For medium farmers, average cultivable land was 3.39 acres which was about 2-3 times larger than that of small farmers.

In each category, some farmers increased their crop land through tenurial arrangement. Since small farmers owned small areas of land, they rented in cultivable land to produce crops and vegetables to increase food production and improve food security. However, the average size of rented land was relatively larger for small farmers compared to those for medium farmers. This indicates that small farmers have surplus manpower for crop production. Some of the small and medium farmers under different FS also rented out land, but the average size of rented out land for medium farmers under C-LP-F was larger ( 0.27 acre) compared to small farmers under the FS of C-P-F and C-L-P.
Again, the homestead area was larger for medium farmers than for small farmers. Moreover, some portion of homestead areas were used by farmers to produce vegetables and fruits or kept for stall feeding of animals. However, with such limited areas of land, both small and medium farmers under different FS utilized land rationally to increase food production and ensure better livelihood.

\subsubsection{Agricultural resources of sample farmers}

It was mentioned that, most of the farmers $(>80 \%)$ in Bangladesh are small farmers and some of them are landless. Due to subsistence in nature, agriculture in Bangladesh is characterized by diversified and integrated farming to meet the household requirements and to minimize the risk and uncertainty. Dillon and Hardaker (1993) stated that small farmers have two characteristics - their small size of land in terms of resources and their low level of income. Table 6 shows the agricultural resources owned by the sample farm households under different alternate farming system. Along with the small size of cultivable land (0.72-3.39 acre.), farmers under C-P-F and C-L-P-F owned ponds having average sizes of 0.10 and 0.22 acre, respectively. On the other hand, farmers of C-L-P and C-L-P-F had cattle heads with average number of 5.00 and 6.00, respectively.

\subsection{Existing alternate farming system and socioeconomic condition of small farmers}

\subsubsection{Economic returns of alternate farming system}

Four different exiting farming systems (FS) and their economic returns are shown in Table 7. There are many different FS in the study areas but the selected four FS are major ones. For all the FS, crop is the common component. Again, there are some sub-component of crop such as cereal crops and vegetables. But to make the study simple and for easy estimation, only rice production was considered in crop component and accordingly, costs and returns in producing 
rice under the selected FS were estimated. Per acre total cost of rice production in different FS varied from Tk. 36721 (C-P-F) to 41214 (C-L-P$\mathrm{F})$. However, there was a small variation regarding both costs and returns of producing rice under the selected FS. It may be noted that, among the FS selected, C-L-P-F had the four components where both total cost and gross returns were the highest but its net return was the lowest (Tk.8080) in producing rice. Moreover, per hectare total cost of production (Tk. 36721) and gross return (Tk. 48077) were the lowest in C-P-F system which caused net returns relatively higher compared to other FS. Most of the farm households in rural areas rear poultry birds in scavenging condition. In the study areas, poultry was the second common component for all the selected farm households. Like crop production, C-L-P-F farmers incurred the highest cost (Tk. 1927) and earned the highest gross returns (Tk. 2725) but the net returns (Tk. 798) was the lowest among the selected FS. With the lower total cost (Tk. 1077), C-P farmers had the highest gross margin (Tk. 1703) as well as net return (Tk. 1603). Regarding gross margin and net return, large variation was observed in poultry rearing under the selected FS.
Some small farmers have fish ponds in their homestead areas. Average size of ponds was 0.10 and 0.22 acre for the farmers under C-P-F and C-L-P-F respectively (Table 6). Considering culture and management of fish pond, per acre gross return was higher (Tk. 40080) for the farmers under C-L-P-F compared to those farmers under C-P-F (Tk. 35121) (Table 7). Earlier, livestock (cattle) was reared by almost all the small farmers for cultivation and also for consuming milk and meat. Recently due to changes in land use pattern, lands are occupied throughout the year by cultivation of cereals and other crops and they can not produce fodder and pulse crop for livestock. Accordingly, at present very few farmers rear livestock. Secondly, those farmers who rear livestock, most of them rear in stall feeding condition. Table 6 shows that, average number of livestock (cattle) was 5 and 6 for the FS C-L-P and C-L-P-F, respectively. Considering cost and returns of rearing livestock of these two types of FS, net return per farm was higher (Tk. 42619) in FS C-L-P compared to FS C-L-P-F.

Table 5. Size of holdings (acre) and tenurial arrangement of sample farm households

\begin{tabular}{lcccc}
\hline Size of holding, acre & C-P & C-P-F & C-L-P & C-L-P-F \\
\hline Homestead area & 0.08 & 0.11 & 0.16 & 0.24 \\
Cultivable land (a+b+c)-d & 0.72 & 0.82 & 1.87 & 3.39 \\
a) Owned & 0.51 & 0.56 & 1.60 & 3.46 \\
b) Rented in & 0.21 & 0.08 & 0.18 & - \\
c) Leased in / Mortgaged in & - & 0.28 & 0.21 & 0.20 \\
d) Leased out/ Mortgaged our/ Rented out & - & 0.10 & 0.12 & 0.27 \\
Pond & - & 0.10 & - & 0.22 \\
\hline Total size of holding & 0.80 & 1.03 & 2.03 & 3.47 \\
\hline
\end{tabular}

Note: 100 decimal= 1 acre, 247 decimal=1 hectare. 
Table 6. Agricultural resources of sample farm households

\begin{tabular}{lcccc}
\hline Agricultural resources & C-P & C-P-F & C-L-P & C-L-P-F \\
\hline Cultivable land (acre) & 0.72 & 0.82 & 1.87 & 3.39 \\
Pond (acre) & - & 0.10 & - & 0.22 \\
Poultry birds, Nos. & 10.00 & 8.00 & 5.00 & 6.00 \\
\hline Cattle head, Nos. & - & - & 5.00 & 6.00 \\
\hline
\end{tabular}

Table 7. Economics returns of integrated farming under different farming system (FS)

\begin{tabular}{|c|c|c|c|c|}
\hline $\begin{array}{l}\text { Integrated farming and estimated } \\
\text { crops and returns on whole farm basis }\end{array}$ & $\begin{array}{l}\text { Total cost }{ }^{1} \\
\text { (Tk) }\end{array}$ & $\begin{array}{l}\text { Gross return } \\
\text { (Tk) }\end{array}$ & $\begin{array}{l}\text { Gross margin } \\
\text { (Tk.) }\end{array}$ & $\begin{array}{l}\text { Net return } \\
\quad(\mathrm{Tk})\end{array}$ \\
\hline \multicolumn{5}{|l|}{$\underline{\mathrm{C}-\mathrm{P}}$} \\
\hline Crop (Rice), Tk./acre & 37464 & 49595 & 21118 & 12131 \\
\hline Poultry (scavenging) Tk./10 birds & 1077 & 2680 & 1703 & 1603 \\
\hline Total cost and returns & 38541 & 52275 & 22821 & 13734 \\
\hline \multicolumn{5}{|l|}{ C-P-F } \\
\hline Crop (Rice), Tk./acre & 36721 & 48077 & 20344 & 11356 \\
\hline Poultry (scavenging) Tk./8 birds & 1103 & 2595 & 1592 & 1492 \\
\hline Fisheries (Pond fishery), Tk./acre & 27522 & 35121 & 16587 & 7599 \\
\hline Total cost and returns & 65346 & 85793 & 38523 & 20447 \\
\hline \multicolumn{5}{|l|}{ C-L-P } \\
\hline Crop (Rice), Tk./acre & 39490 & 48684 & 18182 & 9194 \\
\hline Livestock (Cattle), Tk./farm & 36131 & 78750 & 43869 & 42619 \\
\hline Poultry (scavenging) Tk./5 birds & 1260 & 2485 & 1325 & 1165 \\
\hline Total cost and returns & 76881 & 129919 & 63376 & 52978 \\
\hline \multicolumn{5}{|l|}{ C-L-P-F } \\
\hline Crop (Rice), Tk./acre & 41214 & 49504 & 17277 & 8080 \\
\hline Livestock (Cattle), Tk./farm & 40789 & 76800 & 37561 & 36011 \\
\hline Fisheries (Pond fishery), Tk./acre & 27968 & 40080 & 19813 & 12113 \\
\hline Poultry (scavenging) Tk./6 birds & 1927 & 2725 & 898 & 798 \\
\hline Total cost and returns & 111898 & 169109 & 75549 & 57002 \\
\hline
\end{tabular}

Table 7 Compiled from estimated value of different FS.

1. Total cost included variable cost and fixed cost for each component of selected FS of integrated farming.

2. Gross return: Values of main product and by product were included. 
The overall scenario of profitability and economic returns of integrated farming under alternate FS are depicted in Table 7 and Fig. 1. For estimating farm income of small farm households, whole farm approach was considered. It may be noted that with the increase of number of farm enterprises caused higher farm income. However, considering the small farm practices and whole farm approach, the net return was higher for C-L-P-F farmers (Tk. 57002) followed by C-L-P (Tk. 52978), CP-F (Tk. 20447) and C-P (Tk. 13734).

\subsubsection{Factors influencing livelihood security}

The focus of this section is to identify the socioeconomic factors that contribute to household income and ensure livelihood security of targeted farm households. Some of the most commonly used factors in the assessment of livelihood security included those related to household income and expenditure, expenditure spent on food, adequacy of food taken, housing structure and facilities, owning household assets, and access to drinking water and sanitation, and other basic needs of farm households.

\subsubsection{Household income}

Household income is all income by all members of a household and household expenditure includes household purchasing and payment, and estimated values of goods and services received. Household income is the main factor contributing of household security for farm households. Sustainable household income ensures the sustainable food security as well as livelihood security for farm households. Annual household income according to alternate FS was the lowest (Tk. 132873) for the small farmers belonging to C-P and the highest (Tk. 320800) for medium farmers following C-L-P-F FS (Table 8). Annual income varied to a small scale in other two categories of farmers. Sources of household income of farm households are shown in Table 8. Agriculture, services, business, remittance, dowry/gift and labour selling were the main sources of household income. Irrespective of categories of farmers under different alternate FS, it was found that relatively medium farmers earned higher farm income and included more enterprises in their farming (Table 8).

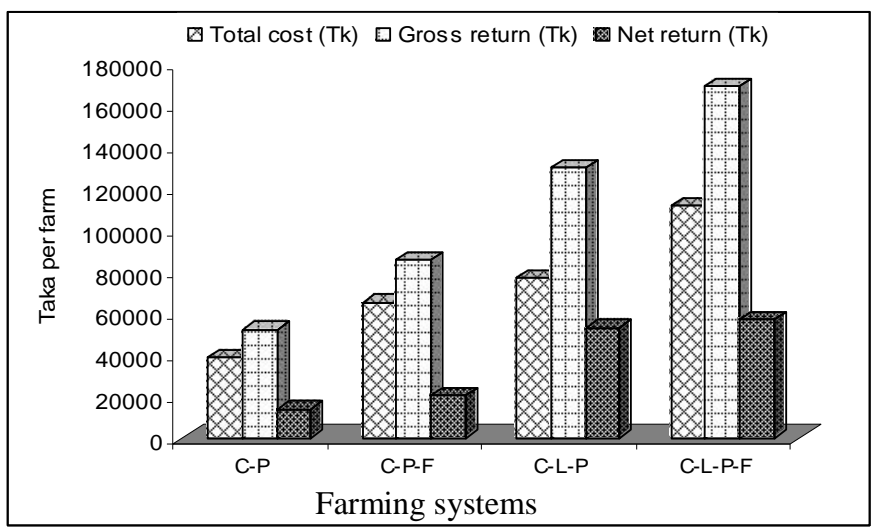

Fig. 1. Total cost, gross return and net return of different categories of farming systems 
Table 8. Sources of farm households' income

\begin{tabular}{lccccc}
\hline \multirow{2}{*}{ Sources } & \multicolumn{5}{c}{ Percentage distribution of household income } \\
\cline { 2 - 6 } & C-P & C-P-F & C-L-P & C-L-P-F & All \\
\hline Agriculture & 55.7 & 73 & 79.7 & 78 & 75.1 \\
Services & 11.9 & 5.5 & 7.4 & 4.9 & 6.9 \\
Business & 24.1 & 14.8 & 7.9 & 11.2 & 12 \\
Remittance & 2.9 & 3.2 & 3.8 & 5.4 & 3.8 \\
Dowry/gift & 1.2 & 1.9 & 0.7 & 0.5 & 1.1 \\
Labor selling and other & 4.3 & 1.6 & 0.4 & 0 & 1.1 \\
\hline Average income (Tk) & 132873 & 248095 & 250398 & 320800 & 238042 \\
\hline
\end{tabular}

Moreover, farmers following different FS earned about $56-80 \%$ of their total household income from farming. As the entire sample farm households were landed farmers, the lion share of household income was earned from agriculture and its contribution was significantly higher for the livelihood security of farm households.

\subsubsection{Household expenditure and savings}

Household expenditure spent on different heads such as food, clothing, health care, education, housing and farming are presented in Tables 9 and 10. It is evident that expenditure spent on food for four different categories of farm households C-P, C-P-F, C-L-P and C-L-P-F were $47,37,29$ and 19\%, respectively. On the other hand, $29-60 \%$ of household expenditure were spent on farming by the sample farm households. It may be noted that irrespective of farm categories under different FS, expenditure spent was the highest $(47 \%)$ for farming followed by 31 and $9 \%$ for food and housing (Table 10). The result implies that most of the farmers spent relatively lower amount on food items which indicates better food security for the farm households.

Table 9 also shows annual income, expenditure and savings of sampled farm households for the year 2008-2009. It is revealed from the table that the entire sample farm households under different FS, had savings ranged from Tk. 12164 to 21736. This implies that the livelihoods of the sampled farm households were secured.

\subsubsection{Adequacy of food taken of farm households}

Qualitative and relative data and information were collected through conducting FGD to estimate the adequacy of food taken by the members of sample farm households. Major food items, and amount and frequencies of food taken in terms of sufficient, moderate by sufficient and insufficient are shown in Table 11.

All sample farm households were sufficient by consuming rice, but vegetables, fish, eggs and dal consumption, were moderate sufficient. However, for other food items, they were either moderate by sufficient or insufficient in food consumption.

\subsubsection{Changing basic needs of farm households}

With the introduction of integrated farming, housing facilities, and supply of safe drinking water and sanitation facilities have increased which helped improve the livelihood security of small farm households (Tables 12 and 13). In stead of using straw roof houses, sample farmers started to live in tin shed and brick wall houses. Again, Table 13 shows that about 67 and $45 \%$ of sample farmers used hand tube-well (HTW) and 
Table 9. Annual income, expenditure and savings (Tk) of farm households during 2008-09

\begin{tabular}{lccccc}
\hline \multirow{2}{*}{ Households income and saving } & \multicolumn{5}{c}{ Farm households } \\
\cline { 2 - 6 } & C-P & C-P-F & C-L-F & C-L-P-F & All farms \\
\hline Household Income & 132873 & 24809 & 250398 & 320800 & 238042 \\
Household Expenditure & 120709 & 23578 & 235227 & 299064 & 222696 \\
\hline Household Savings/Dis-saving & 12164 & 12311 & 15171 & 21736 & 15346 \\
\hline
\end{tabular}

Table 10. Heads of household expenditure of farm households

\begin{tabular}{|c|c|c|c|c|c|c|}
\hline \multirow{2}{*}{ Heads of expenditure } & & \multicolumn{5}{|c|}{ Percentage distribution of household expenditure } \\
\hline & & C-P & \multirow{2}{*}{$\begin{array}{c}\text { C-P-F } \\
37\end{array}$} & \multirow{2}{*}{$\begin{array}{c}\text { C-L-F } \\
29\end{array}$} & \multirow{2}{*}{$\begin{array}{c}\text { C-L-P-F } \\
19\end{array}$} & \multirow{2}{*}{$\begin{array}{c}\text { All farms } \\
31\end{array}$} \\
\hline Food & & 47 & & & & \\
\hline Clothing & & 6 & 5 & 4 & 4 & 5 \\
\hline Medicare & & 3 & 3 & 2 & 1 & 2 \\
\hline Education & & 4 & 5 & 5 & 4 & 5 \\
\hline Housing & & 7 & 7 & 10 & 10 & 9 \\
\hline Farming & & 29 & 41 & 47 & 60 & 47 \\
\hline Others* & & 3 & 3 & 2 & 1 & 2 \\
\hline Average expenditure $(\mathrm{Tk})$ & & 120709 & 235784 & 235227 & 299064 & 222696 \\
\hline \multicolumn{7}{|l|}{ *Soap, cosmetics, etc. } \\
\hline $\begin{array}{l}\text { Food items } \\
\text { consumed }\end{array}$ & C-P & C-P-F & & C-L-F & & P-F \\
\hline Rice & $S$ & $S$ & & $S$ & & \\
\hline Ruti & I & I & & I & & \\
\hline Vegetables & M & $\mathrm{M}$ & & M & & \\
\hline Meat & I & M & & M & & \\
\hline Fish & $\mathrm{M}$ & M & & M & & \\
\hline Eggs & $\mathrm{M}$ & M & & M & & \\
\hline Dal & $\mathrm{M}$ & M & & M & & \\
\hline Fruits & I & I & & I & & \\
\hline Milk & I & I & & M & & \\
\hline
\end{tabular}

S = Sufficient, $\mathrm{M}=$ Moderate sufficient, I = Insufficient 
Table 12. Housing facilities of farm households

\begin{tabular}{lccccc}
\hline \multirow{2}{*}{ Housing types } & \multicolumn{5}{c}{ Percentage distribution of farm households } \\
\cline { 2 - 6 } & C-P & C-P-F & C-L-F & C-L-P-F & All farm \\
\hline Brick wall house & 5 & 25 & 30 & 40 & 25 \\
Tin shed & 80 & 90 & 92 & 100 & 92 \\
Straw roof houses & 20 & 15 & 21 & 10 & 17 \\
\hline
\end{tabular}

Table 13. Household water and sanitation facilities of farm households

\begin{tabular}{lccccc}
\hline \multirow{2}{*}{$\begin{array}{l}\text { Water and sanitation } \\
\text { facilities }\end{array}$} & \multicolumn{5}{c}{ Percentage distribution farm households } \\
\cline { 2 - 6 } & C-P & C-P-F & C-L-F & C-L-P-F & All farm \\
\hline HTW & 60 & 65 & 63 & 85 & 67 \\
Pacca toilet & 30 & 36 & 50 & 65 & 45 \\
Katcacre toilet & 54 & 47 & 31 & 12 & 36 \\
\hline
\end{tabular}

Table 14. Tangible assets of farm households

\begin{tabular}{lccccc}
\hline \multirow{2}{*}{ Tangible assets } & \multicolumn{5}{c}{ Percentage distribution of farm households } \\
\cline { 2 - 6 } & C-P & C-P-F & C-L-F & C-L-P-F & All farm \\
\hline Refrigerator & - & 2 & 5 & 7 & 3 \\
Watch & 40 & 50 & 68 & 82 & 60 \\
Chair/table & 65 & 75 & 70 & 93 & 76 \\
Cot & 30 & 53 & 64 & 85 & 58 \\
Electric fan & 5 & 10 & 45 & 65 & 32 \\
\hline
\end{tabular}

Table 15. Gender participation in home-based productive activities

\begin{tabular}{lcccccccc}
\hline \multirow{2}{*}{$\begin{array}{c}\text { Gender } \\
\text { participation }\end{array}$} & $\begin{array}{c}\text { Poultry } \\
\text { rearing }\end{array}$ & $\begin{array}{c}\text { Cattle } \\
\text { rearing }\end{array}$ & $\begin{array}{c}\text { Milch } \\
\text { cow } \\
\text { rearing }\end{array}$ & $\begin{array}{c}\text { Goat/ } \\
\text { sheep } \\
\text { rearing }\end{array}$ & Sewing & $\begin{array}{c}\text { Vegetable } \\
\text { production }\end{array}$ & $\begin{array}{c}\text { Vegetable } \\
\text { selling }\end{array}$ & $\begin{array}{c}\text { Nursery } \\
\text { reforestation }\end{array}$ \\
\hline Male & 2 & 55 & 50 & 30 & - & 15 & 85 & 40 \\
Female & 98 & 45 & 50 & 70 & 100 & 85 & 15 & 60 \\
\hline
\end{tabular}

${ }^{1}$ Cow with a calf and producing milk 
pacca toilet, respectively. Secondly, most of the sample farmers could afford to buy and used watch, chair/table and cot as tangible assets (Table 14). However, access to enjoy all these households' facilities indicated that the small farmers following different alternate FS under integrated farming improved their livelihood with the present farming condition.

\subsection{Gender participation and home based productive work}

Both men and women were engaged in different household activities. Results of the study indicate that male members of small farm households were engaged in all field based activities, while female members actively participated in home based income generating activities (IGA). Other studies (Taj Uddin and Takey, 2006) reported that conventional farming could not generate needed employment opportunities for small farm households. By practicing integrated farming, unemployment decreased with the increases in farm size and the farmers had very few labour surplus compared to conventional farmers. Female persons play vital role especially in home based activities (Sobhan and Khondaker, 2001). Table 15 shows that with enterprises combination of alternate FS, farmers themselves and their household women were involved in rearing poultry and livestock, kitchen gardening and sewing cloths for household use and nursery reforestation.

\section{Conclusions}

With the changing land use patterns and extension of diversified farming, small farmers included more enterprises in farm practices to have better food security and improving livelihood. Moreover, with the increased number of farm enterprises, achieved higher income of the selected small farm households. Considering whole farm approach, the farm income as well as net return of farm enterprises was higher for farmers belonging to C-L-P-F FS compared to C-L-P, C-P-F and C-P farmers. Socioeconomic factors such as household income, expenditure on food, household structure and facilities, and access to drinking water and sanitation were found better at present farming system practiced by small farmers. Regarding gender role and gender participation, the study showed that most of the women were involved in homestead income generating activities. They were also involved in household decision making with the introduction of integrated farming in small farm condition.

\section{References}

BBS. 2009. The Yearbook of Agricultural Statistics of Bangladesh. Bangladesh Bureau of Statistics (BBS), Statistics Division, Ministry of Planning, Government of the People's Republic of Bangladesh, Dhaka.

Dillon J. L. and Hardaker J. B. 1993. Farm Management Research for Small Farmer Development. Food and Agriculture Organization of the United Nation.

Hossain, S. M. A 1996. The Farming System and Environmental Studies of Bangladesh Agricultural University -An Overview. Edited in Fact Searching and Intervention 1991-95, Part I System Studies. Farming system and Environmental Studies, BAU, Mymensingh, 38-39 pp.

Islam, M. S. and Bakshi, B. C. 1992. "Cash Interflow in Diversified Agriculture-a farm level study in a selected area of Bangladesh". Paper presented at the Regional Seminar on Diversification of Agriculture in Bangladesh held in 25 November at BAU, Mymensingh.

Islam, M. S., Kacren, K. A. and Kabir, M. H. 1999. An Economic Study on Small- scale Household Based Farming and Involvement of Women. Edited in Fact Searching and Intervention 1996-98. Farming system and Environmental studies, BAU, Mymensingh, 168-170 pp.

Sobhan, R. and Khondaker, N. 2001. Globalization and Gender-Cacrenging Pattern of Women's Employment in Bangladesh, CPD. The University Press Limited, 114 Motijheel C/A, Dhaka. 
Taj Uddin, $\mathrm{M}$ and Takeya, H. 2005. Employment Patterns and Income Generation of Farm Households in Integrated Farming in Bangladesh. International Journal of Agricultural Research, USA, 1(1):32-40.

Taj Uddin, M and Takeya, H. 2006. Economic Analysis of Integrated Farming by Agricultural Enterprise in Mymensingh District of Bangladesh. Journal
Agricultural Development Studies, Japan, 16(1): L 40-49.

Taj Uddin, M. and Takeya, H 2007. Integrated Farming in Some Selected Areas of Bangladesh: Resource Interdependence and Enterprise Combination Perspective. The Journal of Rural Development, 34(2):107126. 